\title{
Selection of a bioassay battery to assess toxicity in the affluents and effluents of three water-treatment plants
}

\author{
Paola Bohórquez-Echeverry ${ }^{1}$, Marcela Duarte-Castañeda ${ }^{1}$, Nubia León-López ${ }^{2}$, Fabián Caicedo-Carrascal ${ }^{1}$, \\ Myriam Vásquez-Vásquez, Claudia Campos-Pinilla ${ }^{1 *}$ \\ ${ }^{1}$ Grupo de Biotecnología Ambiental e Industrial (GBAI). Departamento de Microbiología. Facultad de Ciencias. Pontificia Universidad Javeriana. \\ Bogotá, D.C. Colombia. \\ ${ }^{2}$ Empresa de Acueducto y Alcantarillado de Bogotá. Bogotá, D.C. Colombia. \\ *campos@javeriana.edu.co
}

Received; 08-05-2012; Accepted: 10-07-2012

\begin{abstract}
Objective. The assessment of water quality includes the analysis of both physical-chemical and microbiological parameters. However, none of these evaluates the biological effect that can be generated in ecosystems or humans. In order to define the most suitable organisms to evaluate the toxicity in the affluent and effluent of three drinking-water treatment plants, five acute toxicity bioassays were used, incorporating three taxonomic groups of the food chain. Materials and methods. The bioassays used were Daphnia magna and Hydra attenuata as animal models, Lactuca sativa and Pseudokirchneriella subcapitata as plant models, and Photobacterium leioghnathi as bacterial model. To meet this objective, selection criteria of the organisms evaluated and cluster analysis were used to identify the most sensitive in the affluent and effluent of each plant. Results. All organisms are potentially useful in the assessment of water quality by meeting four essential requirements and 17 desirable requirements equivalent to $100 \%$ acceptability, except $P$. leioghnathi which does not meet two essential requirements that are the $\mathrm{IC}_{50}$ for the toxic reference and the confidence interval. The animal, plant and bacterial models showed different levels of sensitivity at the entrance and exit of the water treatment systems. Conclusions. H. attenuata, $P$. subcapitata and $P$. leioghnathi were the most effective organisms in detecting toxicity levels in the affluents and $D$. magna, $P$. subcapitata and $P$. leioghnathi in the effluents.
\end{abstract}

Key words: bioassays, cluster analysis, drinking water, raw water, toxicity.

\section{Resumen}

Selección de una batería de bioensayos para evaluar toxicidad en los afluentes y efluentes de tres plantas potabilizadoras. Objetivo. La evaluación de la calidad del agua incluye el análisis de parámetros tanto físico-químicos como microbiológicos. Sin embargo, ninguno de estos evalúa el efecto biológico que se puede generar en los ecosistemas o en el hombre. Con el objetivo de definir los organismos más indicados para evaluar la toxicidad en el afluente y efluente de tres plantas potabilizadoras, se utilizaron cinco bioensayos de toxicidad aguda, incorporando tres grupos taxonómicos de la cadena trófica. Materiales y métodos. Los bioensayos empleados fueron Daphnia magna e Hydra attenuata como modelos animales, Lactuca sativa y Pseudokirchneriella subcapitata como modelos vegetales y Photobacterium leioghnathi como modelo bacteriano. Para cumplir con este objetivo, se utilizaron criterios de selección de los organismos a evaluar y análisis de conglomerados (AC) para identificar los más sensibles en los afluentes y efluentes de cada una de las plantas. Resultados. Todos los bioensayos son pruebas potencialmente útiles para evaluar la calidad del agua, al presentar cuatro requisitos esenciales y 17 requisitos deseables, salvo $P$. leioghnathi que no cumple con dos de los requisitos esenciales que son la $\mathrm{CI}_{50}$ para los tóxicos de referencia y el intervalo de confianza. En los modelos animales, vegetales y bacteriano se observaron 
diferentes niveles de sensibilidad a la entrada y salida de los sistemas de potabilización. Conclusiones. H. attenuata, $P$. subcapitata y $P$. leioghnathi fueron los organismos más eficaces para detectar la toxicidad en los afluentes y D. magna, P. subcapitata y P. leioghnathi en los efluentes.

Palabras clave: bioensayos, análisis de conglomerados, agua potable, agua cruda, toxicidad.

\begin{abstract}
Resumo
Seleção de uma bateria de bioensaios para avaliar a toxicidade em afluente e efluente de três estações potabilizadoras. Objetivo. A avaliação da qualidade da água inclui a análise dos parâmetros físico-químicos e microbiológicos. No entanto, nenhum destes avalia o efeito a nível biológico que pode ser gerado nos ecossistemas ou no homem. Com o objetivo de definir os organismos mais adequados para avaliar a toxicidade no afluente e efluente de três estações potabilizadoras, foram utilizados cinco bioensaios de toxicidade aguda, incorporando três grupos taxonômicos da cadeia alimentar. Materiais e métodos. Os bioensaios utilizados foram Daphnia magna e Hydra attenuata como modelos animais, Lactuca sativa e Pseudokirchneriella subcapitata como modelos vegetais e Photobacterium leioghnathi como modelo bacteriano. Para cumprir com este objetivo foram utilizados critérios de seleção dos organismos a avaliar e análise de agrupamento (AC), para definir os mais sensíveis nos afluentes e efluentes de cada estação de tratamento. Resultados. Todos os bioensaios são testes potencialmente úteis para avaliar a qualidade da água ao apresentar 4 requisitos essenciais e 17 requisitos desejáveis; exceto $P$. leioghnathi que não cumpre com dois dos requisitos essenciais: com o $\mathrm{CI}_{50}$ para substâncias tóxicas de referência e com o intervalo de confiança. Nos modelos animais, vegetais e bacteriano, foram observados níveis diferentes de sensibilidade à entrada e à saída dos sistemas de potabilização. Conclusões. H. attenuata, $P$. subcapitata e $P$. leioghnathi foram os organismos mais eficazes na detecção de toxicidade em afluentes e D. magna, P. subcapitata e P. leioghnathi nos efluentes.
\end{abstract}

Palavras-chave: bioensaios, análise de agrupamento, água potável, água sem tratamento, toxicidade.

\section{Introduction}

The discharge of wastewater into a water body involves a large number and diversity of chemicals, many of which are unknown. These substances can be mixed among them, increasing or decreasing the toxic effect and generating a negative impact on the structure and functioning of the natural ecosystem.

The tools commonly used to assess pollution in wastewater are based on physicochemical analyses such as $\mathrm{pH}$, dissolved oxygen, Biological Oxygen Demand (BOD), Chemical Oxygen Demand (COD), Total Organic Carbon (TOC), Total Dissolved Solids (TDS) and Total Suspended Solids (TSS), (1-3), which do not reflect the biological effects that pollution can cause in animals, plants and humans. A good alternative to assess such effects are bioassays $(4,5)$.

To assess the toxicity of wastewater and drinking water, different types of bioassays have been used with fish, protozoa, bacteria, algae and others (6) Organisms to assess toxicity are diverse in their composition and their sensitivity to toxicants; therefore, a battery of bioassays is often used instead of a single species to cover a wide range of sensitivities $(1,7,8)$. The test organisms included in a battery include representatives of the food chain at the level of consumers, producers and decomposers (9). The criteria for selection of the battery include autochthonous populations, in particular those that are environmentally attractive, with broad distribution and easy to maintain in the laboratory (10-12).

Keddy et al. (9) proposed a decision-making approach that consists in assessing whether organisms meet some essential criteria such as easy access to publications, standard test methods, acceptability, confidence intervals of $95 \%$, and other desirable criteria like organisms identified by species, measurable endpoint, frequency of observation, environmental test conditions and statistical analysis, among others. Criteria are assigned a weight; if they are over $80 \%$ of acceptability they can be recommended as candidates to make part of a battery. Once organisms are selected, their sensitivity to polluted water is evaluated, and then those organisms that are most useful are chosen to make part of the battery of bioassays.

The selection of organisms that are part of the battery of bioassays can be performed by using multivariate analysis and/or by combining some of them such as non-linear mapping, principal component analysis, cluster analysis (CA) or matching factors analysis (13-14). The cluster analysis is a mathematical tool used to classify objects or variables into groups based on their similarities. The clustering procedure is often initiated by the conversion of raw data into a similarity matrix. Pandard et al. (15) mentioned that this mathematical technique can lead to various structures in the dendrogram given small errors in the distances calculated from the matrix of similarities. 
Bioassays to assess toxicity in Colombia were adopted after Decree 1575 of 2007, which states that any drinking water supply must have at the entrance to the treatment plant, and if possible in the water collection, an early warning system to detect the possible early toxic contamination in the water and to take precautionary measures and strategies for environmental management. Additionally, a risk map should be established for inspection, monitoring and control of risks associated with the conditions of the quality of the sources supplying water for human consumption.

To meet these requirements, the Bogota Water and Sewerage Company considered necessary to implement a battery of bioassays for analysing affluents and effluents of three drinking water treatment plants that supply the city of Bogota. To select this battery, we evaluated two animal models: Daphnia magna and Hydra attenuata; three model plants: Lactuca sativa, Allium cepa and Pseudokirchneriella subcapitata (formerly Selenastrum capricornutum); and a bacterial model: Photobacterium leioghnathi (16-24).

\section{Materials and methods}

\section{Test organisms}

\section{Animal models}

Daphnia magna (25).

It is a static acute toxicity bioassay ( $48 \mathrm{~h}$ of exposure), in which $30 \mathrm{ml}$ plastic containers are used with $25 \mathrm{ml}$ of volume solution. As a positive control we used $0.13 \mathrm{mg} \mathrm{Cr}^{+6} / \mathrm{L}$ with confidence intervals between 0.05 and $0.21 \mathrm{mg} \mathrm{Cr}^{+6} / \mathrm{L}$, and reconstituted hard water as a negative control. Three replicates were performed for each control and dilution. In each container 10 neonates $24 \mathrm{~h}$-old were transferred. The neonates were observed after $24 \mathrm{~h}$ and $48 \mathrm{~h}$ of incubation at $21 \pm 1^{\circ} \mathrm{C}$, with a photoperiod of $16 \mathrm{~h}$ light/8h dark, and a light intensity of 800 lux, and the number of dead organisms was recorded. Based upon the dead counts, we calculated the lethal concentration $50\left(\mathrm{LC}_{50}\right)$ at $48 \mathrm{~h}$ using the Probit method with a significance level of $P<0.05$.

\section{Hydra attenuata (26).}

It is a static test of acute toxicity ( $96 \mathrm{~h}$ of exposure), in which culture plates from 12 wells are used. As a positive control we used $0.78 \mathrm{mg} \mathrm{Cr}^{+6} / \mathrm{L}$ with confidence intervals between 0.73 and $0.83 \mathrm{mg} \mathrm{Cr}^{+6} / \mathrm{L}$ and reconstituted hard water as a negative control. Three replicates were performed for each control and dilution: in each well three hydras were transferred to a volume of $4 \mathrm{ml}$ of the solution and incubated at a temperature of $20 \pm 2{ }^{\circ} \mathrm{C}$, a light intensity of 800 lux and a photoperiod of $16 \mathrm{~h} \mathrm{light} / 8 \mathrm{~h}$ dark. The morphological changes of the test organisms were recorded at 24, 48, 72 and $96 \mathrm{~h}$ of exposure. Morphology includes a normal stage, two of sublethality (organisms with rounded and shortened tentacles), and two of lethality (tentacles tulip-shaped and disintegrated organisms). With this assay we determined the average concentration that produces an effect in the exposed population (sublethal $\mathrm{EC}_{50}$ or lethal $\mathrm{LC}_{50}$ ) using the Probit method with a significance level of $P<0.05$.

\section{Vegetable model}

Lactuca sativa (27).

It is a static acute toxicity test (120 h of exposure) with Lactuca sativa variety Great Lake Batavia. In the test, 25 seeds of similar size, shape, and colour are placed on a Whatman No. 3 filter paper impregnated with $4 \mathrm{ml}$ of sample in a Petri Dish and incubated at $22 \pm 2{ }^{\circ} \mathrm{C}$ in

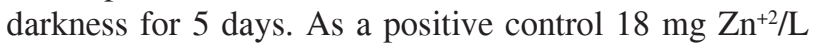
were used with confidence intervals between 6.8 and $30 \mathrm{mg}$ $\mathrm{Zn}^{+2} / \mathrm{L}$, and reconstituted hard water as a negative control. After incubation, the average length of roots per sample concentration is recorded and five outliers are discarded to reduce the coefficient of variation in the results. Finally, the concentration that produces $50 \%$ inhibition in root elongation $\left(\mathrm{IC}_{50}\right)$ is estimated using the Probit method with a significance level of $P<0.05$.

\section{Pseudokirchneriella subcapitata (28).}

It is a static acute toxicity test with $P$. subcapitata $(96 \mathrm{~h}$ of exposure). In the test, 18 25-ml Erlenmeyer flasks are used with a $10 \mathrm{ml}$ solution volume. As a positive control $0.25 \mathrm{mg} \mathrm{Cr}^{+6} / \mathrm{L}$ with confidence intervals between 0.05 and $0.46 \mathrm{mg} \mathrm{Cr}^{+6} / \mathrm{L}$ was used and culture medium as a negative control. For each control and dilution three replicates were performed. The volume calculated from the culture is inoculated in each Erlenmeyer flask to set an initial cell density of $10^{4}$ cell $/ \mathrm{ml}$. Subsequently, the cultures are incubated at $23 \pm 2{ }^{\circ} \mathrm{C}$, light intensity of $4.300 \pm 10$ lux and at continuous agitation of 100 revolutions per minute. After the incubation period of $96 \mathrm{~h}$ the percentage of inhibition is determined for each concentration compared to the control turbidity at 750 nanometres and the concentration that produces $50 \%$ of inhibition in the growth of algal cells $\left(\mathrm{IC}_{50}\right)$ is calculated with the Probit method with a significance level of $P<0.05$ 


\section{Bacterial model}

Photobacterium leioghnathi (29).

Bioluminescence test is used to determine the toxicity of compounds that interfere with the enzymatic system of bacteria causing a reduction in light output. Variations in light output are measured with a high sensitivity luminometer (1 femtomole) at a wavelength of 490 nanometers. ToxScreen II test (CheckLight $®$ Ltda.) includes the use of two buffers, one that favours the detection of heavy metals (Pro-Metal Buffer) and another one (Pro-Organic Buffer) that favours the detection of organic pollution. Toxicity is determined by the average effective or inhibitory concentration $\left(\mathrm{IC}_{50}\right.$ (15-30 minutes) $30^{\circ} \mathrm{C}$ ) in a given time and under controlled temperature. $\mathrm{The} \mathrm{CI}_{50}$ is calculated when the inhibitory effect is greater than or equal to $50 \%$, otherwise it is reported as a percentage of volume/volume effect.

\section{Selection criteria for organisms}

The first step in selecting the organisms of the battery in the affluent and effluent from three treatment plants was to apply the approach of Keddy et al. (9) which states that the following requirements must be met:

\section{Essential requirements}

1. To have easy access to the publications reported as standard test methods.

2. To have toxic reference values and their actual or median lethal concentration.

3. To have acceptability criteria, ideally associated to confidence intervals of $95 \%$.

4. To have controls to ensure the health of test organisms to carry out the bioassays and the interpretation of results.

\section{Desirable requirements}

There were 12 inclusion criteria to be met by the test organisms and each criterion was assigned a score. The scores for each criterion were assigned as follows:

1. Test organisms identified by species (1)

2. Measurable endpoints (1)

3. Morphological characteristics of the test organism (1)

4. Number of organisms per replicate (1)
5. Frequency of observation (1)

6. Volume of test solution (1)

7. Volume of test containers (1)

8. Preparation of the test substance and its addition to the test container (2)

9. Continued cultivation of the organisms (1)

10. Environmental test conditions (3)

11. Definition of culture media and dilution (2)

12. Statistical analysis (2)

When methods meet the four essential requirements, tests are considered as 'potentially useful'; then they are analysed to find whether they meet all the desirable requirements to be regarded on the long term as 'prototype tests', that is both inclusion criteria mentioned above must be complemented to become 'useful tests'. When the analysed organism meets the 12 desirable criteria, it gets 17 points equivalent to $100 \%$ of acceptability for desirable requirements. In this case all the indicators to be evaluated obtained 17 points, which are equivalent to $100 \%$ of acceptability for desirable requirements. In addition to the selection of organisms, relevant information was considered for the application of the tests, such as representing the trophic level, sensitivity, reproducibility (coefficient of variation in control charts $\leq$ $30 \%$ ) and ecological relevance, all criteria that complement the tests and make them more robust to be recommended in a battery of bioassays (9).

\section{Water samples}

Ten samples of raw water (affluent) and 10 samples of treated water (effluent) were taken from three drinking-water treatment plants that supply the city of Bogotá, Colombia. The water samples from the three treatment plants comply with national legislation. Given the physicochemical characteristics of the three affluents, they were analysed as untreated wastewater.

The Tibitoc plant collects water from Bogotá River to be treated by a conventional system, which consists of a presedimentation, coagulation, flocculation, sedimentation, downward flow filtration through a bed of anthracite, and gas chlorination. El Dorado plant collects water from La Regadera water reservoir and its treatment is a pre-treatment where the water is stabilized with hydrated lime, coagulation, flocculation, sedimentation, downflow filtration through a bed of anthracite and gas chlorination, and finally a dosing 
with lime to stabilize the $\mathrm{pH}$ of the water. The Francisco Wiesner plant collects water from two sources: the Chingaza Paramo and the San Rafael reservoir in which water is stored from the Chingaza Paramo and the Teusacá River. Its treatment is a direct filtration with sand and anthracite, and gas chlorination. The average flow treated in plants is $8.50 \mathrm{~m}^{3} / \mathrm{s}$ for Tibitoc, $11.75 \mathrm{~m}^{3} / \mathrm{s}$ for El Dorado, and 0.35 $\mathrm{m}^{3} / \mathrm{s}$ for Francisco Wiesner.

Two litres of water were collected from each affluent and effluent at different days of the week to get a better assessment of variation of input water and the operation of each plant. Water samples were refrigerated at $4^{\circ} \mathrm{C}$ during transportation to the laboratory and were analysed within $48 \mathrm{~h}$ after collection.

We used as test organisms two animal models: D. magna and H. attenuate; three vegetable models: L. sativa, $P$. subcapitata and Allium cepa; and a bacterial model: Photobacterium leioghnathi. The results of A. серa are not included in this study because of the difficulty in obtaining homogeneous onion bulbs, so we obtained a coefficient of variation of $59 \%$ in the control card.

In the bioassay with P. leioghnathi, the effluent samples were processed with chlorine and chlorine neutralizing with sodium thiosulfate pentahydrate $3 \%(60 \mu \mathrm{l} / 50 \mathrm{ml}$ of treated water).

\section{Data analysis}

Calculation of $\mathrm{LC} / \mathrm{EC} / \mathrm{IC}_{50}$

To calculate the $\mathrm{LC} / \mathrm{EC} / \mathrm{IC}_{50}$ and their $95 \%$ confidence limits, the Probit method was used (EPA, V). This is a parametric method to estimate the effective concentration or lethality $\left(\mathrm{EC}_{50}\right.$ or $\left.\mathrm{LC}_{50}\right)$ by adjusting mortality data with a technique or effect of probability. One of the restrictions of the method is that to calculate the $\mathrm{EC}_{50}$ or $\mathrm{LC}_{50}$ intermediate values should be obtained between 0 and $100 \%$ effect. When results in $\mathrm{EC}$ or $\mathrm{LC}_{50}$ cannot be reported by the demands of the statistical program, they are reported as the percentage of effect in the lowest concentration at which the event is still present on the evaluated population. The effects may be inhibition, sub-lethality and lethality or volume/volume.

\section{Cluster analysis}

CA was used for the selection of the battery of bioassays (13, 15). Cluster analysis is a mathematical tool that classifies objects or variables into groups. The procedure begins with the conversion of raw data into a similarity matrix. We used the method of classification by hierarchical clustering (linkage Intra-Group), whose graphical representation is a dendrogram (15). To calculate the distance matrix between the values of each bioassay, the results were consolidated at $100 \%$ effect, using the measure of the Chi-2. CA as a mathematical tool can lead to various structures in the dendrogram, providing small errors in the distances calculated from the similarity matrix.

\section{Results}

\section{Selection criteria for organisms}

The selection of organisms used to evaluate the affluent and effluent water of the treatment plants was conducted according to the scheme proposed by Keddy et al (9). Bioassays to identify whether they met this proposal took into account the four key requirements and the 12 desirable qualifications to determine if they are considered useful tests (Tables 1 and 2). The analysis found that all organisms are potentially useful to meet four key requirements and 17 points for the desirable qualifications, equivalent to $100 \%$ acceptability. P. leioghnathi does not meet two essential requirements: the $\mathrm{CI}_{50}$ for the toxic reference and the confidence interval.

\section{Battery of Bioassays}

Regarding the analysis of toxicity in animal, plant and bacterial models, there were different levels of sensitivity to input and output of water treatment systems.

In the affluent of Francisco Wiesner plant (Table 3), $H$. attenuata presented sublethal effects in most samples with $\mathrm{EC}_{50}$ values between 49.6 and 107.42 and case lethality rates between 11.1 and $100 \%$. D. magna showed low sensitivity in mortality rates between 4 and $57 \%$ to $100 \%$. In the plant model, a similar sensitivity was observed in bioassays $P$. subcapitata and $L$. sativa. The algae growth presented an inhibition in $70 \%$ of the samples and the rest of the growth stimulation assays. In weeks 6 and 8, L. sativa showed growth-stimulating effects while other samples observed inhibition of root growth between 1 and $20 \%$. In the case of plant models, when the volume/ volume percentage is greater than $100 \%$ effect, it indicates that there has been an overgrowth of algal cells and/or root elongation compared to the negative control, so it is also seen as a sign of toxicity. In the bacterial model, $P$. leioghnathi; showed sensitivity only to organic in week 1 , exceeding a 50\% inhibition as suggested by the protocol. 
Table 1. Results of the essential requirements application for the organism selection.

\begin{tabular}{|c|c|c|c|c|}
\hline & \multicolumn{4}{|c|}{ Essential requirements } \\
\hline Test organism & Test Method & $\begin{array}{c}\text { Toxic reference } \\
\text { endpoint } \\
\mathrm{IC}_{50} / \mathrm{LC}_{50}\end{array}$ & $\begin{array}{l}\text { Confidence } \\
\text { Intervals }\end{array}$ & Controls \\
\hline H. attenuata & $\begin{array}{c}\text { Trottier et al. } \\
1997\end{array}$ & $\begin{array}{l}0.80 \mathrm{mg} \mathrm{Cr}^{+6} / \mathrm{L} \\
\mathrm{LC}_{50-96} \mathrm{~h}\end{array}$ & $95 \%$ & $\begin{array}{c}\text { (+) Chrome } \\
\text { (-) Reconstituted hard water }\end{array}$ \\
\hline D. magna & McInnis 1989 & $\begin{array}{c}0.15 \mathrm{mg} \mathrm{Cr}^{+6} / \mathrm{L} \\
\mathrm{LC}_{50-48} \mathrm{~h}\end{array}$ & $95 \%$ & $\begin{array}{c}\text { (+) Chrome } \\
\text { (-) Reconstituted hard water }\end{array}$ \\
\hline L. sativa & McInnis 1989 & $\begin{array}{l}20 \mathrm{mg} \mathrm{Zn}^{+2} / \mathrm{L} \\
\mathrm{IC}_{50-120} \mathrm{~h}\end{array}$ & $95 \%$ & $\begin{array}{c}(+) \text { Zinc } \\
(-) \text { Distilled water }\end{array}$ \\
\hline P. subcapitata & EPA 1994 & $\begin{array}{c}0.30 \mathrm{mg} \mathrm{Cr}^{+6} / \mathrm{L} \\
\mathrm{IC}_{50-96} \mathrm{~h}\end{array}$ & $95 \%$ & $\begin{array}{c}\text { (+) Chrome } \\
\text { (-) Culture medium }\end{array}$ \\
\hline P. leioghnathi & $\begin{array}{l}\text { Standard } \\
\text { methods } \\
8050 \mathrm{~B}\end{array}$ & N.A & N.A & $\begin{array}{l}\text { (+) Sodium chloroacetate } \\
\text { (pro-organic Buffer) } \\
\text { Cupric chloride } \\
\text { (pro-metallic Buffer) } \\
\text { (-) Deionized water }\end{array}$ \\
\hline
\end{tabular}

N.A: Not Applicable. (+): Positive control. (-): Negative control

Table 2. Results of the desirable requirements application for organism selection.

\begin{tabular}{|c|c|c|c|c|c|c|c|c|c|c|c|c|c|}
\hline \multicolumn{14}{|c|}{ Desirable requirements } \\
\hline 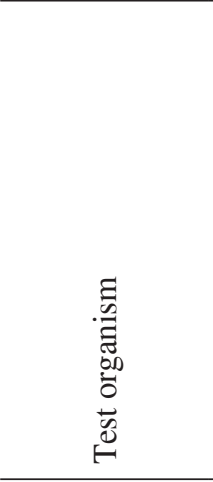 & 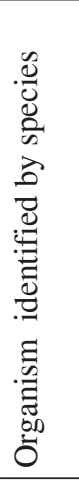 & 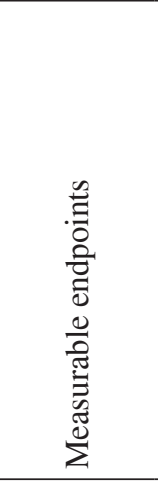 & 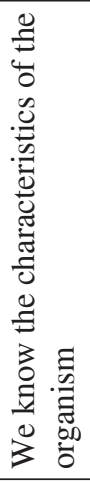 & 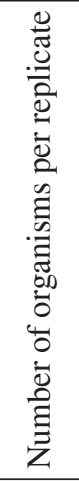 & 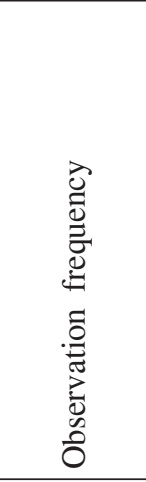 & 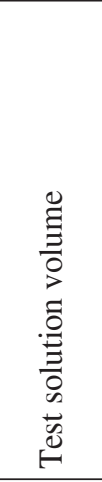 & 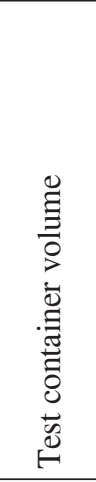 & 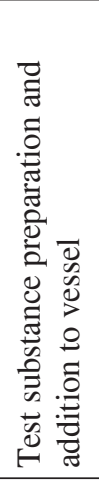 & 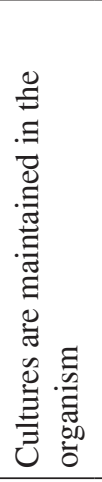 & 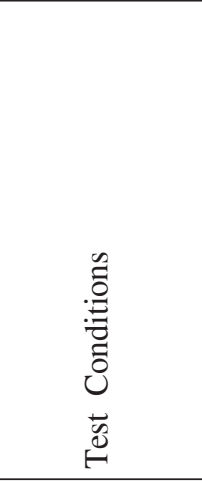 & 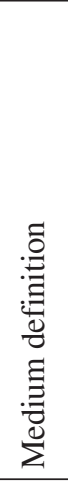 & 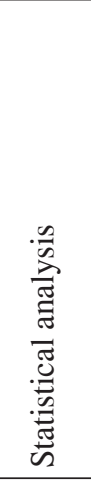 & 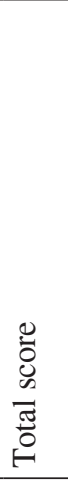 \\
\hline H. attenuata & Yes & $\begin{array}{l}\text { Sublethal } \\
\text { lethality }\end{array}$ & Yes & 9 & $\begin{array}{l}24,48, \\
72,96 \mathrm{~h}\end{array}$ & $4 \mathrm{ml}$ & $5 \mathrm{ml}$ & Yes & Yes & $\begin{array}{c}800 \text { lux, } \\
20 \pm 2^{\circ} \mathrm{C} \\
16 \text { h light/8 h } \\
\text { dark }\end{array}$ & Yes & $\begin{array}{c}\mathrm{EC}_{50} \\
\mathrm{y} / \mathrm{o} \\
\mathrm{LC}_{50}\end{array}$ & 17 \\
\hline D. magna & Yes & Mortality & Yes & 10 & $24,48 \mathrm{~h}$ & $30 \mathrm{ml}$ & $35 \mathrm{ml}$ & Yes & Yes & $\begin{array}{c}800 \text { lux } \\
21 \pm 2{ }^{\circ} \mathrm{C} \\
16 \text { h light } / 8 \mathrm{~h} \\
\text { dark }\end{array}$ & Yes & $\mathrm{LC}_{50}$ & 17 \\
\hline L. sativa & Yes & Inhibition & Yes & 25 & $120 \mathrm{~h}$ & $4 \mathrm{ml}$ & $55 \mathrm{ml}$ & Yes & No & $\begin{array}{c}22 \pm 2{ }^{\circ} \mathrm{C} \\
\text { dark } \\
\end{array}$ & Yes & $\mathrm{IC}_{50}$ & 17 \\
\hline P. subcapitata & Yes & Inhibition & Yes & 3 & $24,96 \mathrm{~h}$ & $10 \mathrm{ml}$ & $25 \mathrm{ml}$ & Yes & Yes & $\begin{array}{l}4300 \text { lux, } \\
21-25^{\circ} \mathrm{C}\end{array}$ & Yes & $\mathrm{IC}_{50}$ & 17 \\
\hline P. leioghnathi & Yes & Inhibition & Yes & N.A. & $\begin{array}{c}0,15,30 \\
\text { minutes }\end{array}$ & $1 \mathrm{ml}$ & $3 \mathrm{ml}$ & Yes & No & $30^{\circ} \mathrm{C}$ & Yes & $\mathrm{IC}_{50}$ & 17 \\
\hline
\end{tabular}

N.A: Not Applicable 
Table 3. Bioassay results from the Francisco Wiesner plant affluent.

\begin{tabular}{|c|c|c|c|c|c|}
\hline Week & $\begin{array}{c}\text { H. attenuata } \\
\text { EC }_{50-96 \mathrm{~h}} \\
\text { or } \\
\% \quad(\mathrm{v} / \mathrm{v}) \text { Effect }\end{array}$ & $\begin{array}{c}\text { D. magna } \\
\text { LC }_{\mathbf{5 0 - 4 8}} \\
\text { or } \\
\%(\mathrm{v} / \mathrm{v}) \text { Effect }\end{array}$ & $\begin{array}{l}\text { P. subcapitata } \\
\text { IC }_{50-96 \mathrm{~h}} \\
\text { or } \\
\%(\mathrm{v} / \mathrm{v}) \text { Effect }\end{array}$ & $\begin{array}{c}\text { L. sativa } \\
\text { IC }_{50-120 \mathrm{~h}} \\
\text { or } \\
\%(\mathrm{v} / \mathrm{v}) \text { Effect }\end{array}$ & $\begin{array}{l}\text { P. leioghnathi } \\
\text { IC }_{50-30 \text { min }} \\
\text { or } \\
\%(\text { v/v) Effect }\end{array}$ \\
\hline 1 & $\begin{array}{c}\text { Lethality } \\
11.1 \% \text { al } 100 \%\end{array}$ & $\begin{array}{c}\text { Mortality } \\
0 \% \text { al } 100 \%\end{array}$ & $\begin{array}{l}\text { Overgrowth } \\
141 \% \text { al } 100 \%\end{array}$ & $\begin{array}{l}\text { Inhibition } \\
11 \% \text { al } 100 \%\end{array}$ & $\begin{array}{l}\text { Inhibition } \\
\text { Inorganic } 0 \% \text { al } 100 \% \\
\text { Organic } 52 \% \text { al } 100 \%\end{array}$ \\
\hline 2 & EC 49.06 & $\begin{array}{l}\text { Mortality } \\
7 \% \text { al } 100 \%\end{array}$ & $\begin{array}{l}\text { Overgrowth } \\
201 \% \text { al } 100 \%\end{array}$ & $\begin{array}{l}\text { Inhibition } \\
8 \% \text { al } 100 \%\end{array}$ & $\begin{array}{c}\text { Inhibition } \\
\text { Inorganic } 20 \% \text { al } 100 \% \\
\text { Organic } 22 \% \text { al } 100 \%\end{array}$ \\
\hline 3 & EC 107.42 & $\begin{array}{c}\text { Mortality } \\
17 \% \text { al } 100 \%\end{array}$ & $\begin{array}{l}\text { Overgrowth } \\
136 \% \text { al } 100 \%\end{array}$ & $\begin{array}{l}\text { Inhibition } \\
5 \% \text { al } 100 \%\end{array}$ & $\begin{array}{c}\text { Inhibition } \\
\text { Inorganic } 0 \% \text { al } 100 \% \\
\text { Organic } 22 \% \text { al } 100 \%\end{array}$ \\
\hline 4 & EC 55.82 & $\begin{array}{l}\text { Mortality } \\
4 \% \text { al } 100 \%\end{array}$ & $\begin{array}{l}\text { Inhibition } \\
18 \% \text { al } 100 \%\end{array}$ & $\begin{array}{l}\text { Inhibition } \\
1 \% \text { al } 100 \%\end{array}$ & $\begin{array}{c}\text { Inhibition } \\
\text { Inorganic } 0 \% \text { al } 100 \% \\
\text { Organic } 38.5 \% \text { al } 100 \%\end{array}$ \\
\hline 5 & $\begin{array}{c}\text { Lethality } \\
100 \% \text { al } 100 \%\end{array}$ & $\begin{array}{c}\text { Mortality } \\
57 \% \text { al } 100 \%\end{array}$ & $\begin{array}{l}\text { Overgrowth } \\
125 \% \text { al } 100 \%\end{array}$ & $\begin{array}{l}\text { Inhibition } \\
17 \% \text { al } 100 \%\end{array}$ & $\begin{array}{l}\text { Inhibition } \\
\text { Inorganic } 27 \% \text { al } 100 \% \\
\text { Organic } 21.9 \% \text { al } 100 \%\end{array}$ \\
\hline 6 & EC 86.06 & $\begin{array}{l}\text { Mortality } \\
0 \% \text { al } 100 \%\end{array}$ & $\begin{array}{l}\text { Inhibition } \\
6 \% \text { al } 100 \%\end{array}$ & $\begin{array}{l}\text { Overgrowth } \\
115 \% \text { al } 100 \%\end{array}$ & $\begin{array}{c}\text { Inhibition } \\
\text { Inorganic } 0 \% \text { al } 100 \% \\
\text { Organic } 0 \% \text { al } 100 \%\end{array}$ \\
\hline 7 & $\begin{array}{c}\text { Lethality } \\
100 \% \text { al } 100 \%\end{array}$ & LC 77.79 & $\begin{array}{l}\text { Inhibition } \\
14 \% \text { al } 100 \%\end{array}$ & $\begin{array}{c}\text { Inhibition } \\
20 \% \text { al } 100 \%\end{array}$ & $\begin{array}{c}\text { Inhibition } \\
\text { Inorganic } 6 \% \text { al } 100 \% \\
\text { Organic } 0 \% \text { al } 100 \%\end{array}$ \\
\hline 8 & EC 90.19 & $\begin{array}{c}\text { Mortality } \\
0 \% \text { al } 100 \%\end{array}$ & $\begin{array}{l}\text { Inhibition } \\
10 \% \text { al } 100 \%\end{array}$ & $\begin{array}{l}\text { Overgrowth } \\
109 \% \text { al } 100 \%\end{array}$ & $\begin{array}{c}\text { Inhibition } \\
\text { Inorganic } 0 \% \text { al } 100 \% \\
\text { Organic } 0 \% \text { al } 100 \%\end{array}$ \\
\hline 9 & EC 88.17 & $\begin{array}{c}\text { Mortality } \\
0 \% \text { al } 100 \%\end{array}$ & $\begin{array}{l}\text { Inhibition } \\
8 \% \text { al } 100 \%\end{array}$ & $\begin{array}{l}\text { Inhibition } \\
8 \% \text { al } 100 \%\end{array}$ & $\begin{array}{c}\text { Inhibition } \\
\text { Inorganic } 0 \% \text { al } 100 \% \\
\text { Organic } 28 \% \text { al } 100 \%\end{array}$ \\
\hline 10 & $\begin{array}{c}\text { Sublethality } \\
55.6 \% \text { al } 100 \%\end{array}$ & $\begin{array}{c}\text { Mortality } \\
0 \% \text { al } 100 \%\end{array}$ & $\begin{array}{l}\text { Inhibition } \\
20 \% \text { al } 100 \%\end{array}$ & $\begin{array}{l}\text { Inhibition } \\
1 \% \text { al } 100 \%\end{array}$ & $\begin{array}{c}\text { Inhibition } \\
\text { Inorganic } 0 \% \text { al } 100 \% \\
\text { Organic } 0 \% \text { al } 100 \%\end{array}$ \\
\hline
\end{tabular}

At El Dorado plant (Table 4), H. attenuata showed sublethality rates in most trials with $\mathrm{EC}_{50}$ values between 25.32 and 177.80 . D. magna presented mortality rates in $70 \%$ of the processed samples, with values between 9 and $36 \%$. The model plants (L. sativa and P. subcapitata) showed a similar behaviour, presenting percentages of inhibition and stimulation of growth. P. leioghnathi showed no toxicity in any sampling event.

In the affluent of the Tibitoc Plant (Table 5), the indicator $H$. attenuata presented sublethality effects of 22.2 and $55.6 \%$ in the undiluted sample (weeks 7 and 9), $\mathrm{EC}_{50}$ values between 30.51 and 130.62 in two events and an $\mathrm{EC}_{50}$ of 82.48 and 55.54. D. magna showed toxicity in $60 \%$ of the samples, with values between $23 \%$ and $100 \%$ in the second week, and $\mathrm{EC}_{50}$ of 151.73 . P. subcapitata presented growth inhibition between 5 and $11 \%$ at week 4 and an $\mathrm{EC}_{50}$ value of 56.10. Other results show a stimulating effect, overcoming a $100 \%$ effect with respect to the negative control. L. sativa presented, in the same proportion, stimulation and inhibition. P. leioghnathi did not exhibit this kind of sensitivity to water.

In the effluent of Francisco Wiesner Plant (Table 6), Hydra attenuata exhibited sensitivity in all the effluent samples except for week 3 . The sample 10 yielded a value of $100 \%$ sub-lethality and lethality in weeks 5, 6, 7 and 9 with values between 33.3 and 66.7\%. Daphnia magna showed toxicity in the 10 samples tested indicating a high 
Table 4. Bioassay results from the El Dorado plant affluent.

\begin{tabular}{|c|c|c|c|c|c|}
\hline Week & $\begin{array}{c}\text { H. attenuata } \\
\text { EC }_{50-96 \mathrm{~h}} \\
\text { or } \\
\%(\mathrm{v} / \mathrm{v}) \\
\text { Effect }\end{array}$ & $\begin{array}{c}\text { D. magna } \\
\text { LC }_{50-48 ~ h} \\
\text { or } \\
\%(\mathrm{v} / \mathrm{v}) \\
\text { Effect }\end{array}$ & $\begin{array}{c}\text { P. subcapitata } \\
\text { IC }_{50-96 \mathrm{~h}} \\
\text { or } \\
\%(\mathrm{v} / \mathrm{v}) \\
\text { Effect }\end{array}$ & $\begin{array}{c}\text { L. sativa } \\
\text { IC }_{\text {50-120 h }} \\
\text { or } \\
\%(\mathrm{v} / \mathrm{v}) \\
\text { Effect }\end{array}$ & $\begin{array}{c}\text { P. leioghnathi } \\
\text { IC }_{50-30 \min } \\
\text { or } \\
\%(\mathrm{v} / \mathrm{v}) \\
\text { Effect }\end{array}$ \\
\hline 1 & $\begin{array}{c}\text { Sublethality } \\
22.2 \% \text { al } 100 \%\end{array}$ & $\begin{array}{c}\text { Mortality } \\
20 \% \text { al } 100 \%\end{array}$ & $\begin{array}{c}\text { Overgrowth } \\
138 \% \text { al } 100 \%\end{array}$ & $\begin{array}{c}\text { Inhibition } \\
9 \% \text { al } 100 \%\end{array}$ & $\begin{array}{c}\text { Inhibition } \\
\text { Inorganic } 0 \% \text { al } 100 \% \\
\text { Organic } 22 \% \text { al } 100 \%\end{array}$ \\
\hline 2 & $\begin{array}{l}\text { Sublethality } \\
0 \% \text { al } 100 \%\end{array}$ & CL 76.44 & $\begin{array}{l}\text { Overgrowth } \\
207 \% \text { al } 100 \%\end{array}$ & $\begin{array}{c}\text { Overgrowth } \\
110 \% \text { al } \\
100 \%\end{array}$ & $\begin{array}{c}\text { Inhibition } \\
\text { Inorganic } 20 \% \text { al } 100 \% \\
\text { Organic } 0 \% \text { al } 100 \%\end{array}$ \\
\hline 3 & EC 68.54 & $\begin{array}{c}\text { Mortality } \\
36 \% \text { al } 100 \%\end{array}$ & $\begin{array}{c}\text { Inhibition } \\
22 \% \text { al } 100 \%\end{array}$ & $\begin{array}{l}\text { Inhibition } \\
3 \% \text { al } 100 \%\end{array}$ & $\begin{array}{c}\text { Inhibition } \\
\text { Inorganic } 0 \% \text { al } 100 \% \\
\text { Organic } 30 \% \text { al } 100 \%\end{array}$ \\
\hline 4 & EC 73.80 & $\begin{array}{c}\text { Mortality } \\
13 \% \text { al } 100 \%\end{array}$ & $\begin{array}{l}\text { Overgrowth } \\
109 \% \text { al } 100 \%\end{array}$ & $\begin{array}{l}\text { Inhibition } \\
4 \% \text { al } 100 \%\end{array}$ & $\begin{array}{c}\text { Inhibition } \\
\text { Inorganic } 43 \% \text { al } 100 \% \\
\text { Organic } 6,2 \% \text { al } 100 \%\end{array}$ \\
\hline 5 & EC 177.80 & $\begin{array}{c}\text { Mortality } \\
0 \% \text { al } 100 \%\end{array}$ & $\begin{array}{l}\text { Overgrowth } \\
105 \% \text { al } 100 \%\end{array}$ & $\begin{array}{c}\text { Overgrowth } \\
120 \% \text { al } \\
100 \%\end{array}$ & $\begin{array}{c}\text { Inhibition } \\
\text { Inorganic } 0 \% \text { al } 100 \% \\
\text { Organic } 0 \% \text { al } 100 \%\end{array}$ \\
\hline 6 & EC 62.70 & $\begin{array}{l}\text { Mortality } \\
9 \% \text { al } 100 \%\end{array}$ & $\begin{array}{c}\text { Inhibition } \\
17 \% \text { al } 100 \%\end{array}$ & $\begin{array}{c}\text { Overgrowth } \\
104 \% \text { al } \\
100 \%\end{array}$ & $\begin{array}{c}\text { Inhibition } \\
\text { Inorganic } 10 \% \text { al } 100 \% \\
\text { Organic } 0 \% \text { al } 100 \%\end{array}$ \\
\hline 7 & EC 125.82 & $\begin{array}{c}\text { Mortality } \\
14 \% \text { al } 100 \%\end{array}$ & $\begin{array}{l}\text { Inhibition } \\
9 \% \text { al } 100 \%\end{array}$ & $\begin{array}{c}\text { Overgrowth } \\
104 \% \text { al } \\
100 \%\end{array}$ & $\begin{array}{c}\text { Inhibition } \\
\text { Inorganic } 0 \% \text { al } 100 \% \\
\text { Organic } 0 \% \text { al } 100 \%\end{array}$ \\
\hline 8 & EC 95.53 & $\begin{array}{l}\text { Mortality } \\
0 \% \text { al } 100 \%\end{array}$ & $\begin{array}{c}\text { Inhibition } \\
17 \% \text { al } 100 \%\end{array}$ & $\begin{array}{l}\text { Inhibition } \\
1 \% \text { al } 100 \%\end{array}$ & $\begin{array}{c}\text { Inhibition } \\
\text { Inorganic } 0 \% \text { al } 100 \% \\
\text { Organic } 0 \% \text { al } 100 \%\end{array}$ \\
\hline 9 & EC 25.32 & $\begin{array}{c}\text { Mortality } \\
20 \% \text { al } 100 \%\end{array}$ & $\begin{array}{l}\text { Overgrowth } \\
103 \% \text { al } 100 \%\end{array}$ & $\begin{array}{l}\text { Inhibition } \\
7 \% \text { al } 100 \%\end{array}$ & $\begin{array}{c}\text { Inhibition } \\
\text { Inorganic } 0 \% \text { al } 100 \% \\
\text { Organic } 41 \% \text { al } 100 \%\end{array}$ \\
\hline 10 & EC 130.62 & $\begin{array}{c}\text { Mortality } \\
0 \% \text { al } 100 \%\end{array}$ & $\begin{array}{l}\text { Inhibition } \\
6 \% \text { al } 100 \%\end{array}$ & $\begin{array}{c}\text { Overgrowth } \\
112 \% \text { al } \\
100 \%\end{array}$ & $\begin{array}{c}\text { Inhibition } \\
\text { Inorganic } 0 \% \text { al } 100 \% \\
\text { Organic } 0 \% \text { al } 100 \%\end{array}$ \\
\hline
\end{tabular}

Table 5. Results of bioassays from the Tibitoc plant affluent.

\begin{tabular}{|c|c|c|c|c|c|}
\hline Week & $\begin{array}{c}\text { H. attenuata } \\
\text { EC/LC }{ }_{50-96 \mathrm{~h}} \\
\text { or } \\
\%(\mathrm{v} / \mathrm{v}) \text { Effect }\end{array}$ & $\begin{array}{c}\text { D. magna } \\
\text { LC }_{50-48 \mathrm{~h}} \\
\text { or } \\
\%(\mathrm{v} / \mathrm{v}) \text { Effect }\end{array}$ & $\begin{array}{c}\text { P. subcapitata } \\
\text { IC }_{50-96 \mathrm{~h}} \\
\text { or } \\
\%(\mathrm{v} / \mathrm{v}) \text { Effect }\end{array}$ & $\begin{array}{c}\text { L. sativa } \\
\text { IC }_{50-120 \mathrm{~h}} \\
\text { or } \\
\%(\mathrm{v} / \mathrm{v}) \text { Effect }\end{array}$ & $\begin{array}{l}\text { P. leioghnathi } \\
\text { IC }_{50-30 \min } \\
\text { or } \\
\%(\mathrm{v} / \mathrm{v}) \text { Effect }\end{array}$ \\
\hline 1 & LC 82.48 & $\begin{array}{c}\text { Mortality } \\
23 \% \text { to } 100 \%\end{array}$ & $\begin{array}{l}\text { Overgrowth } \\
140 \% \text { to } 100 \%\end{array}$ & $\begin{array}{l}\text { Inhibition } \\
8 \% \text { to } 100 \%\end{array}$ & $\begin{array}{c}\text { Inhibition } \\
\text { Inorganic } 0 \% \text { to } 100 \% \\
\text { Organic } 22 \% \text { to } 100 \%\end{array}$ \\
\hline 2 & EC 30.51 & LC 151.73 & $\begin{array}{l}\text { Overgrowth } \\
273 \% \text { to } 100 \%\end{array}$ & $\begin{array}{l}\text { Inhibition } \\
8 \% \text { to } 100 \%\end{array}$ & $\begin{array}{c}\text { Inhibition } \\
\text { Inorganic } 20 \text { to } 100 \% \\
\text { Organic } 11 \% \text { to } 100 \%\end{array}$ \\
\hline 3 & EC 64.38 & $\begin{array}{l}\text { Mortality } \\
7 \% \text { to } 100 \%\end{array}$ & $\begin{array}{l}\text { Overgrowth } \\
121 \% \text { to } 100 \%\end{array}$ & $\begin{array}{l}\text { Overgrowth } \\
110 \% \text { to } 100 \%\end{array}$ & $\begin{array}{c}\text { Inhibition } \\
\text { Inorganic } 0 \% \text { to } 100 \% \\
\text { Organic } 26 \% \text { to } 100 \%\end{array}$ \\
\hline
\end{tabular}




\begin{tabular}{|c|c|c|c|c|c|}
\hline 4 & LC 55.54 & $\begin{array}{l}\text { Mortality } \\
13 \% \text { to } 100 \%\end{array}$ & IC 56.10 & $\begin{array}{l}\text { Inhibition } \\
4 \% \text { to } 100 \%\end{array}$ & $\begin{array}{c}\text { Inhibition } \\
\text { Inorganic } 0 \% \text { to } 100 \% \\
\text { Organic } 28.6 \% \text { to } 100 \%\end{array}$ \\
\hline 5 & EC 130.62 & $\begin{array}{l}\text { Mortality } \\
3 \% \text { to } 100 \%\end{array}$ & $\begin{array}{l}\text { Overgrowth } \\
124 \% \text { to } 100 \%\end{array}$ & $\begin{array}{l}\text { Overgrowth } \\
101 \% \text { to } 100 \%\end{array}$ & $\begin{array}{c}\text { Inhibition } \\
\text { Inorganic } 0 \% \text { to } 100 \% \\
\text { Organic } 6.5 \% \text { to } 100 \%\end{array}$ \\
\hline 6 & EC 55.88 & $\begin{array}{l}\text { Mortality } \\
3 \% \text { to } 100 \%\end{array}$ & $\begin{array}{l}\text { Inhibition } \\
5 \% \text { to } 100 \%\end{array}$ & $\begin{array}{l}\text { Overgrowth } \\
110 \% \text { to } 100 \%\end{array}$ & $\begin{array}{c}\text { Inhibition } \\
\text { Inorganic } 10 \% \text { to } 100 \% \\
\text { Organic } 0 \% \text { to } 100 \%\end{array}$ \\
\hline 7 & $\begin{array}{c}\text { Sublethality } \\
22.2 \% \text { to } 100 \%\end{array}$ & $\begin{array}{c}\text { Mortality } \\
0 \% \text { to } 100 \%\end{array}$ & $\begin{array}{l}\text { Overgrowth } \\
105 \% \text { to } 100 \%\end{array}$ & $\begin{array}{l}\text { Inhibition } \\
1 \% \text { to } 100 \%\end{array}$ & $\begin{array}{c}\text { Inhibition } \\
\text { Inorganic } 0 \% \text { to } 100 \% \\
\text { Organic } 0 \% \text { to } 100 \%\end{array}$ \\
\hline 8 & EC 55.76 & $\begin{array}{c}\text { Mortality } \\
0 \% \text { to } 100 \%\end{array}$ & $\begin{array}{l}\text { Inhibition } \\
7 \% \text { to } 100 \%\end{array}$ & $\begin{array}{l}\text { Overgrowth } \\
111 \% \text { to } 100 \%\end{array}$ & $\begin{array}{c}\text { Inhibition } \\
\text { Inorganic } 0 \% \text { to } 100 \% \\
\text { Organic } 0 \% \text { to } 100 \%\end{array}$ \\
\hline 9 & $\begin{array}{l}\text { Sublethality } \\
55.6 \% \text { to } 100 \%\end{array}$ & $\begin{array}{l}\text { Mortality } \\
0 \% \text { to } 100 \%\end{array}$ & $\begin{array}{l}\text { Inhibition } \\
6 \% \text { to } 100 \%\end{array}$ & $\begin{array}{l}\text { Inhibition } \\
9 \% \text { to } 100 \%\end{array}$ & $\begin{array}{c}\text { Inhibition } \\
\text { Inorganic } 0 \% \text { to } 100 \% \\
\text { Organic } 32 \% \text { to } 100 \%\end{array}$ \\
\hline 10 & EC 66.72 & $\begin{array}{c}\text { Mortality } \\
0 \% \text { to } 100 \%\end{array}$ & $\begin{array}{l}\text { Inhibition } \\
11 \% \text { to } 100 \%\end{array}$ & $\begin{array}{c}\text { Overgrowth } \\
123 \% \\
\text { to } 100 \%\end{array}$ & $\begin{array}{c}\text { Inhibition } \\
\text { Inorganic } 0 \% \text { to } 100 \% \\
\text { Organic } 0 \% \text { to } 100 \%\end{array}$ \\
\hline
\end{tabular}

Table 6. Bioassay results from the Francisco Wiesner plant effluent.

\begin{tabular}{|c|c|c|c|c|c|}
\hline Week & $\begin{array}{c}\text { H. attenuata } \\
\text { EC }_{50-96 \mathrm{~h}} \\
\text { or } \\
\%(\mathrm{v} / \mathrm{v}) \text { Effect }\end{array}$ & $\begin{array}{c}\text { D. magna } \\
\text { LC }_{50-48 \mathrm{~h}} \\
\text { or } \\
\%(\mathrm{v} / \mathrm{v}) \text { Effect }\end{array}$ & $\begin{array}{l}\text { P. subcapitata } \\
\text { IC }_{50-96 \mathrm{~h}} \\
\text { or } \\
\%(\mathrm{v} / \mathrm{v}) \text { Effect }\end{array}$ & $\begin{array}{c}\text { L. sativa } \\
\text { IC }_{\text {50-120 h }} \\
\text { or } \\
\%(\mathrm{v} / \mathrm{v}) \text { Effect }\end{array}$ & $\begin{array}{l}\text { P. leioghnathi } \\
\text { IC }_{50-30 \min } \\
\text { or } \\
\%(\mathrm{v} / \mathrm{v}) \text { Effect }\end{array}$ \\
\hline 1 & EC 26.02 & LC 2.08 & $\begin{array}{l}\text { Overgrowth } \\
176 \% \text { al } 100 \%\end{array}$ & $\begin{array}{c}\text { Inhibition } \\
9 \% \text { al } 100 \%\end{array}$ & $\begin{array}{c}\text { Inhibition } \\
\text { Inorganic } 0 \% \text { al } 100 \% \\
\text { Organic } 42 \% \text { al } 100 \%\end{array}$ \\
\hline 2 & EC 84.10 & LC 12.19 & $\begin{array}{l}\text { Overgrowth } \\
215 \% \text { al } 100 \%\end{array}$ & $\begin{array}{c}\text { Inhibition } \\
15 \% \text { al } 100 \%\end{array}$ & $\begin{array}{c}\text { Inhibition } \\
\text { Inorganic } 18 \% \text { al } 100 \% \\
\text { Organic } 14 \% \text { al } 100 \%\end{array}$ \\
\hline 3 & $\begin{array}{l}\text { Sublethality } \\
0 \% \text { al } 100 \%\end{array}$ & LC 22.29 & $\begin{array}{l}\text { Overgrowth } \\
121 \% \text { al } 100 \%\end{array}$ & $\begin{array}{c}\text { Inhibition } \\
13 \% \text { al } 100 \%\end{array}$ & $\begin{array}{c}\text { Inhibition } \\
\text { Inorganic } 0 \% \text { al } 100 \% \\
\text { Organic } 32 \% \text { al } 100 \%\end{array}$ \\
\hline 4 & EC 14.64 & LC 10.47 & $\begin{array}{l}\text { Inhibition } \\
59 \% \text { al } 100 \%\end{array}$ & $\begin{array}{l}\text { Inhibition } \\
8 \% \text { al } 100 \%\end{array}$ & $\begin{array}{l}\text { Inhibition } \\
\text { Inorganic } 10.6 \% \text { al } 100 \% \\
\text { Organic } 43.4 \% \text { al } 100 \%\end{array}$ \\
\hline 5 & $\begin{array}{l}\text { Lethality } \\
66.7 \% \text { al } 100 \%\end{array}$ & LC 10.32 & $\begin{array}{l}\text { Inhibition } \\
81 \% \text { al } 100 \%\end{array}$ & $\begin{array}{c}\text { Inhibition } \\
19 \% \text { al } 100 \%\end{array}$ & $\begin{array}{l}\text { Inhibition } \\
\text { Inorganic } 14 \% \text { al } 100 \% \\
\text { Organic } 30.5 \% \text { al } 100 \%\end{array}$ \\
\hline 6 & $\begin{array}{c}\text { Lethality } \\
44.4 \% \text { al } 100 \%\end{array}$ & LC 7.33 & IC 70.30 & $\begin{array}{l}\text { Inhibition } \\
6 \% \text { al } 100 \%\end{array}$ & $\begin{array}{c}\text { Inhibition } \\
\text { Inorganic } 0 \% \text { al } 100 \% \\
\text { Organic } 0 \% \text { al } 100 \%\end{array}$ \\
\hline 7 & $\begin{array}{l}\text { Lethality } \\
33.3 \% \text { al } 100 \%\end{array}$ & $\begin{array}{c}\text { Mortality } \\
100 \% \text { al } 12.5 \%\end{array}$ & IC 80.32 & Inhibition & $\begin{array}{c}\text { Inhibition } \\
\text { Inorganic } 0 \% \text { al } 100 \% \\
\text { Organic } 19.4 \% \text { al } 100 \%\end{array}$ \\
\hline 8 & EC 31.53 & Mortality & IC 28.78 & Inhibition & $\begin{array}{c}\text { Inhibition } \\
\text { Inorganic } 0 \% \text { al } 100 \%\end{array}$ \\
\hline 9 & $\begin{array}{l}\text { Lethality } \\
55.6 \% \text { al } 100 \%\end{array}$ & $\begin{array}{c}21 \% \text { al } 18 \% \\
\text { Mortality } \\
100 \% \text { al } 12.5 \%\end{array}$ & IC 17.79 & $\begin{array}{l}1 \% \text { al } 100 \% \\
\text { Inhibition } \\
24 \% \text { al } 100 \%\end{array}$ & $\begin{array}{l}\text { Organic } 0 \% \text { al } 100 \% \\
\text { Inhibition } \\
\text { Inorganic } 0 \% \text { al } 100 \% \\
\text { Organic } 33 \% \text { al } 100 \%\end{array}$ \\
\hline 10 & $\begin{array}{l}\text { Sublethality } \\
100 \% \text { al } 100 \%\end{array}$ & LC 17.48 & $\begin{array}{c}\text { Inhibition } \\
98 \% \text { al } 100 \%\end{array}$ & $\begin{array}{c}\text { Inhibition } \\
21 \% \text { al } 100 \%\end{array}$ & $\begin{array}{c}\text { Inhibition } \\
\text { Inorganic } 0 \% \text { al } 100 \% \\
\text { Organic } 0 \% \text { al } 100 \%\end{array}$ \\
\hline
\end{tabular}


sensitivity of this organism in this type of water. In $P$. subcapitata we observed inhibition of cell growth in $70 \%$ of the cases and growth was stimulated only in the first three weeks. L. sativa in all samples showed inhibitory effects on root elongation, with values between 1 and $24 \%$ to $100 \%$. P. leioghnathi did not provide sensitivity to possible toxicity by organic or inorganic in 10 samples of water with chlorine neutralization. In water samples without neutralization of chlorine, chlorine concentration was between 2 and $2.8 \mathrm{mg} / \mathrm{l}$.

Table 7 presents the results of toxicity bioassays in the effluent from El Dorado Plant. $H$. attenuata showed toxicity in all samples tested, with $\mathrm{EC}_{50}$ values between
19.89 and 66.15. D. magna showed high rates of mortality and $\mathrm{LC}_{50-48 \mathrm{~h}}$ between 6.44 and 24.53. P. subcapitata showed growth inhibition in $80 \%$ of the cases and stimulation of growth in two samples. L. sativa showed both inhibition and stimulation of growth. Finally, $P$. leioghnathi presented an $\mathrm{IC}_{50-15 \min }$ in the chlorine samples neutralized with sodium thiosulfate pentahydrate only in the first week, indicating toxicity of inorganic origin. The chlorine concentration in El Dorado was between 2.1 and $2.4 \mathrm{mg} / \mathrm{l}$. In the remaining samples no effect of inhibition of bioluminescence was detected.

In the Tibitoc effluent (Table 8), Hydra and Daphnia were sensitive in $100 \%$ of the samples tested, but the Daphnia

Table 7. Results of bioassays from El Dorado plant effluent.

\begin{tabular}{|c|c|c|c|c|c|}
\hline Week & $\begin{array}{l}\text { H. attenuata } \\
\text { EC }_{50-96 \mathrm{~h}} \\
\text { o } \\
\% \text { (v/v) Effect }\end{array}$ & $\begin{array}{c}\text { D. magna } \\
\text { LC }_{50-48 ~ h} \\
\text { Or } \\
\%(v / v) \text { Effect }\end{array}$ & $\begin{array}{l}\text { P. subcapitata } \\
\text { IC }_{50-96 \mathrm{~h}} \\
\text { o } \\
\%(\mathrm{v} / \mathrm{v}) \text { Effect }\end{array}$ & $\begin{array}{c}\text { L. sativa } \\
\text { IC }_{50-120 \mathrm{~h}} \\
\text { o } \\
\%(\mathrm{v} / \mathrm{v}) \text { Effect }\end{array}$ & $\begin{array}{l}\text { P. leioghnathi } \\
\mathrm{IC}_{50-30 \mathrm{~min}} \\
\text { o } \\
\%(\mathrm{v} / \mathrm{v}) \text { Effect }\end{array}$ \\
\hline 1 & EC 38.01 & $\begin{array}{c}\text { Mortality } \\
100 \% \text { al } 12.5 \%\end{array}$ & $\begin{array}{l}\text { Overgrowth } \\
138 \% \text { al } 100 \%\end{array}$ & $\begin{array}{c}\text { Inhibition } \\
9 \% \text { al } 100 \%\end{array}$ & $\begin{array}{c}\text { Inhibition } \\
\text { Inorganic } 54 \% \text { al } 100 \% \\
\mathrm{CI}_{50-15 \min } 10 \\
\text { Organic } 26 \% \text { al } 100 \%\end{array}$ \\
\hline 2 & $\begin{array}{c}\text { Lethality } \\
77.8 \text { al } 100 \%\end{array}$ & LC 19.34 & $\begin{array}{l}\text { Overgrowth } \\
194 \% \text { al } 100 \%\end{array}$ & $\begin{array}{l}\text { Overgrowth } \\
116 \% \text { al } 100 \%\end{array}$ & $\begin{array}{c}\text { Inhibition } \\
\text { Inorganic } 0 \% \text { al } 100 \% \\
\text { Organic } 29 \% \text { al } 100 \% \\
\end{array}$ \\
\hline 3 & $\begin{array}{c}\text { Lethality } \\
100 \text { al } 100 \%\end{array}$ & $\begin{array}{c}\text { Mortality } \\
100 \% \text { al } 12.5 \%\end{array}$ & $\begin{array}{c}\text { Inhibition } \\
84.99 \% \text { al } 100 \%\end{array}$ & $\begin{array}{l}\text { Inhibition } \\
53 \% \text { al } 100 \%\end{array}$ & $\begin{array}{c}\text { Inhibition } \\
\text { Inorganic } 0 \% \text { al } 100 \% \\
\text { Organic } 42 \% \text { al } 100 \% \\
\end{array}$ \\
\hline 4 & EC 66.15 & LC 9.50 & $\begin{array}{l}\text { Inhibition } \\
39 \% \text { al } 100 \%\end{array}$ & $\begin{array}{c}\text { Inhibition } \\
2 \% \text { al } 100 \%\end{array}$ & $\begin{array}{c}\text { Inhibition } \\
\text { Inorganic } 46.5 \% \text { al } 100 \% \\
\text { Organic } 43.9 \% \text { al } 100 \%\end{array}$ \\
\hline 5 & EC 64.54 & $\begin{array}{c}\text { Mortality } \\
87 \% \text { al } 12.5 \%\end{array}$ & IC 46.29 & $\begin{array}{l}\text { Inhibition } \\
14 \% \text { al } 100 \%\end{array}$ & $\begin{array}{c}\text { Inhibition } \\
\text { Inorganic } 6 \% \text { al } 100 \% \\
\text { Organic } 26 \% \text { al } 100 \% \\
\end{array}$ \\
\hline 6 & $\begin{array}{l}\text { Lethality } \\
55.6 \% \text { al } 100 \%\end{array}$ & LC 6.44 & IC 31.21 & $\begin{array}{l}\text { Overgrowth } \\
107 \% \text { al } 100 \%\end{array}$ & $\begin{array}{c}\text { Inhibition } \\
\text { Inorganic } 6 \% \text { al } 100 \% \\
\text { Organic } 0 \% \text { al } 100 \%\end{array}$ \\
\hline 7 & $\begin{array}{c}\text { Lethality } \\
100 \% \text { al } 100 \%\end{array}$ & LC 17.97 & IC 33.03 & $\begin{array}{l}\text { Inhibition } \\
16 \% \text { al } 100 \%\end{array}$ & $\begin{array}{c}\text { Inhibition } \\
\text { Inorganic } 8 \% \text { al } 100 \% \\
\text { Organic } 26.2 \% \text { al } 100 \% \\
\end{array}$ \\
\hline 8 & EC 19.89 & LC 24.53 & $\begin{array}{c}\text { Inhibition } \\
79 \% \text { al } 100 \%\end{array}$ & $\begin{array}{l}\text { Overgrowth } \\
129 \% \text { al } 100 \%\end{array}$ & $\begin{array}{c}\text { Inhibition } \\
\text { Inorganic } 0 \% \text { al } 100 \% \\
\text { Organic } 0 \% \text { al } 100 \% \\
\end{array}$ \\
\hline 9 & $\begin{array}{l}\text { Lethality } \\
77.8 \% \text { al } 100 \%\end{array}$ & $\begin{array}{c}\text { Mortality } \\
100 \% \text { al } 25 \%\end{array}$ & $\begin{array}{c}\text { Inhibition } \\
74 \% \text { al } 100 \%\end{array}$ & $\begin{array}{c}\text { Inhibition } \\
25 \% \text { al } 100 \%\end{array}$ & $\begin{array}{c}\text { Inhibition } \\
\text { Inorganic } 0 \% \text { al } 100 \% \\
\text { Organic } 48 \% \text { al } 100 \% \\
\end{array}$ \\
\hline 10 & $\begin{array}{c}\text { Sublethality } \\
44.4 \% \text { al } 100 \%\end{array}$ & $\begin{array}{c}\text { Mortality } \\
100 \% \text { al } 18 \%\end{array}$ & $\begin{array}{c}\text { Inhibition } \\
88 \% \text { al } 100 \%\end{array}$ & $\begin{array}{l}\text { Overgrowth } \\
108 \% \text { al } 100 \%\end{array}$ & $\begin{array}{c}\text { Inhibition } \\
\text { Inorganic } 0 \% \text { al } 100 \% \\
\text { Organic } 0 \% \text { al } 100 \%\end{array}$ \\
\hline
\end{tabular}


Table 8. Results of bioassays from the Tibitoc plant effluent.

\begin{tabular}{|c|c|c|c|c|c|}
\hline Week & $\begin{array}{l}\text { H. attenuata } \\
\text { EC/LC }_{50-96 ~ h} \\
\mathrm{Or}^{-}\end{array}$ & $\begin{array}{l}\text { D. magna } \\
\text { LC }_{50-48 ~ h} \\
\text { or }\end{array}$ & $\begin{array}{l}\text { P. subcapitata } \\
\text { IC }_{50-96 \mathrm{~h}} \\
\text { or }\end{array}$ & $\begin{array}{l}\text { L. sativa } \\
\text { IC }_{50-120 \mathrm{~h}} \\
\text { or }\end{array}$ & $\begin{array}{l}\text { P. leioghnathi } \\
\mathrm{IC}_{50-30 \mathrm{~min}} \\
\text { or }\end{array}$ \\
\hline & $\%(v / v)$ Effect & $\%(v / v)$ Effect & $\%(v / v)$ Effect & $\%(v / v)$ Effect & $\%(v / v)$ Effect \\
\hline 1 & $\begin{array}{l}\text { Sublethality } \\
33.3 \text { al } 100 \%\end{array}$ & LC 32.83 & $\begin{array}{l}\text { Overgrowth } \\
108 \% \text { al } 100 \%\end{array}$ & $\begin{array}{c}\text { Inhibition } \\
15 \% \text { al } 100 \%\end{array}$ & $\begin{array}{c}\text { Inhibition } \\
\text { Inorganic } 0 \% \text { al } 100 \% \\
\text { Organic } 29 \% \text { al } 100 \%\end{array}$ \\
\hline 2 & EC 74.52 & $\begin{array}{c}\text { Mortality } \\
100 \% \text { al } 12.5 \%\end{array}$ & $\begin{array}{c}\text { Overgrowth } \\
243 \% \text { al } 100 \%\end{array}$ & $\begin{array}{l}\text { Inhibition } \\
4 \% \text { al } 100 \%\end{array}$ & $\begin{array}{c}\text { Inhibition } \\
\text { Inorganic } 0 \% \text { al } 100 \% \\
\text { Organic } 29 \% \text { al } 100 \%\end{array}$ \\
\hline 3 & EC 45.38 & $\begin{array}{c}\text { Mortality } \\
100 \% \text { al } 6.25 \%\end{array}$ & IC 71.34 & $\begin{array}{c}\text { Overgrowth } \\
114 \% \text { al } 100 \%\end{array}$ & $\begin{array}{c}\text { Inhibition } \\
\text { Inorganic } 0 \% \text { al } 100 \% \\
\text { Organic } 30 \% \text { al } 100 \% \\
\end{array}$ \\
\hline 4 & EC24.68 & $\begin{array}{c}\text { Mortality } \\
100 \% \text { al } 25 \%\end{array}$ & IC 71.19 & $\begin{array}{l}\text { Inhibition } \\
1 \% \text { al } 100 \%\end{array}$ & $\begin{array}{c}\text { \%Inhibition } \\
\text { Inorganic } 0 \% \text { al } 100 \% \\
\text { Organic } 43.8 \% \text { al } 100 \%\end{array}$ \\
\hline 5 & EC 67.87 & $\begin{array}{c}\text { Mortality } \\
100 \% \text { al } 25 \%\end{array}$ & IC 62.32 & $\begin{array}{l}\text { Inhibition } \\
5 \% \text { al } 100 \%\end{array}$ & $\begin{array}{c}\text { Inhibition } \\
\text { Inorganic } 0 \% \text { al } 100 \% \\
\text { Organic } 30.8 \% \text { al } 100 \%\end{array}$ \\
\hline 6 & EC 23.64 & $\begin{array}{c}\text { Mortality } \\
100 \% \text { al } 3.12 \%\end{array}$ & IC 35.74 & $\begin{array}{c}\text { Inhibition } \\
105 \% \text { al } 100 \%\end{array}$ & $\begin{array}{c}\text { Inhibition } \\
\text { Inorganic } 0 \% \text { al } 100 \% \\
\text { Organic } 30 \% \text { al } 100 \% \\
\end{array}$ \\
\hline 7 & $\begin{array}{l}\text { Sublethality } \\
55.6 \text { al } 100 \%\end{array}$ & $\begin{array}{c}\text { Mortality } \\
100 \% \text { al } 25 \%\end{array}$ & IC 40.63 & $\begin{array}{l}\text { Inhibition } \\
3 \% \text { al } 100 \%\end{array}$ & $\begin{array}{c}\% \text { Inhibition } \\
\text { Inorganic } 0 \% \text { al } 100 \% \\
\text { Organic } 35 \% \text { al } 100 \%\end{array}$ \\
\hline 8 & EC 26.00 & LC10.48 & $\begin{array}{c}\text { Inhibition } \\
62 \% \text { al } 100 \%\end{array}$ & $\begin{array}{l}\text { Inhibition } \\
9 \% \text { al } 100 \%\end{array}$ & $\begin{array}{c}\text { Inhibition } \\
\text { Inorganic } 7 \% \text { al } 100 \% \\
\text { Organic } 0 \% \text { al } 100 \%\end{array}$ \\
\hline 9 & EC 66.30 & $\begin{array}{c}\text { Mortality } \\
100 \% \text { al } 12.5 \%\end{array}$ & IC 28.93 & $\begin{array}{c}\text { Inhibition } \\
12 \% \text { al } 100 \%\end{array}$ & $\begin{array}{c}\text { Inhibition } \\
\text { Inorganic } 0 \% \text { al } 100 \% \\
\text { Organic } 41 \% \text { al } 100 \%\end{array}$ \\
\hline 10 & EC 32.46 & LC 14.09 & IC 28.89 & $\begin{array}{l}\text { Overgrowth } \\
110 \% \text { al } 100 \%\end{array}$ & $\begin{array}{c}\text { Inhibition } \\
\text { Inorganic } 0 \% \text { al } 100 \% \\
\text { Organic } 0 \% \text { al } 100 \%\end{array}$ \\
\hline
\end{tabular}

had greater mortality rates in the higher dilutions of the sample. Plant models showed no significant difference in terms of response or inhibition of growth effect; however, $P$. subcapitata showed greater sensitivity to the present average $\mathrm{IC}_{50}$ values of 48.43 in $70 \%$ of the samples. Only in the first two weeks showed a stimulating effect on cell growth. L. sativa showed inhibition values between 1 and $15 \%$, and samples from week 3 and week 10 showed a stimulating effect on root elongation. The bacterial model P. leioghnathi did not show toxicity in chlorine neutralizing samples. The chlorine concentration in the effluents was between 3 and $7 \mathrm{mg} / \mathrm{l}$.

\section{Cluster analysis}

For the CA we used data obtained at $100 \%$, i.e. from the undiluted sample. Dendrograms are shown in Figure 1. Bacterial model results with $P$. leioghnathi were excluded from the analysis due to failure to report positive results above $50 \%$ as suggested by the protocol.

The choice of battery for each affluent and effluent of the three treatment plants was based on the comparison of the sensitivity of the test organisms by the CA. We obtained homogeneous groups of organisms, with the same potential for toxicity detection and the same range of sensitivity, with distances below 5 standard units with the Chi- 2 method. In the affluents of Francisco Wiesner and El Dorado, the animal model $H$. attenuata showed a greater homogeneity in the results. For Tibitoc, it was D. magna the organism with the greatest homogeneity. Regarding the plant model, $P$. subcapitata showed a greater homogeneity in the three treatment plants, although $L$. sativa was also highly homogeneous for El Dorado. In the three effluents it can be seen that D. magna and $P$. subcapitata represent greater homogeneity in their behavior, although $H$. attenuata is also 


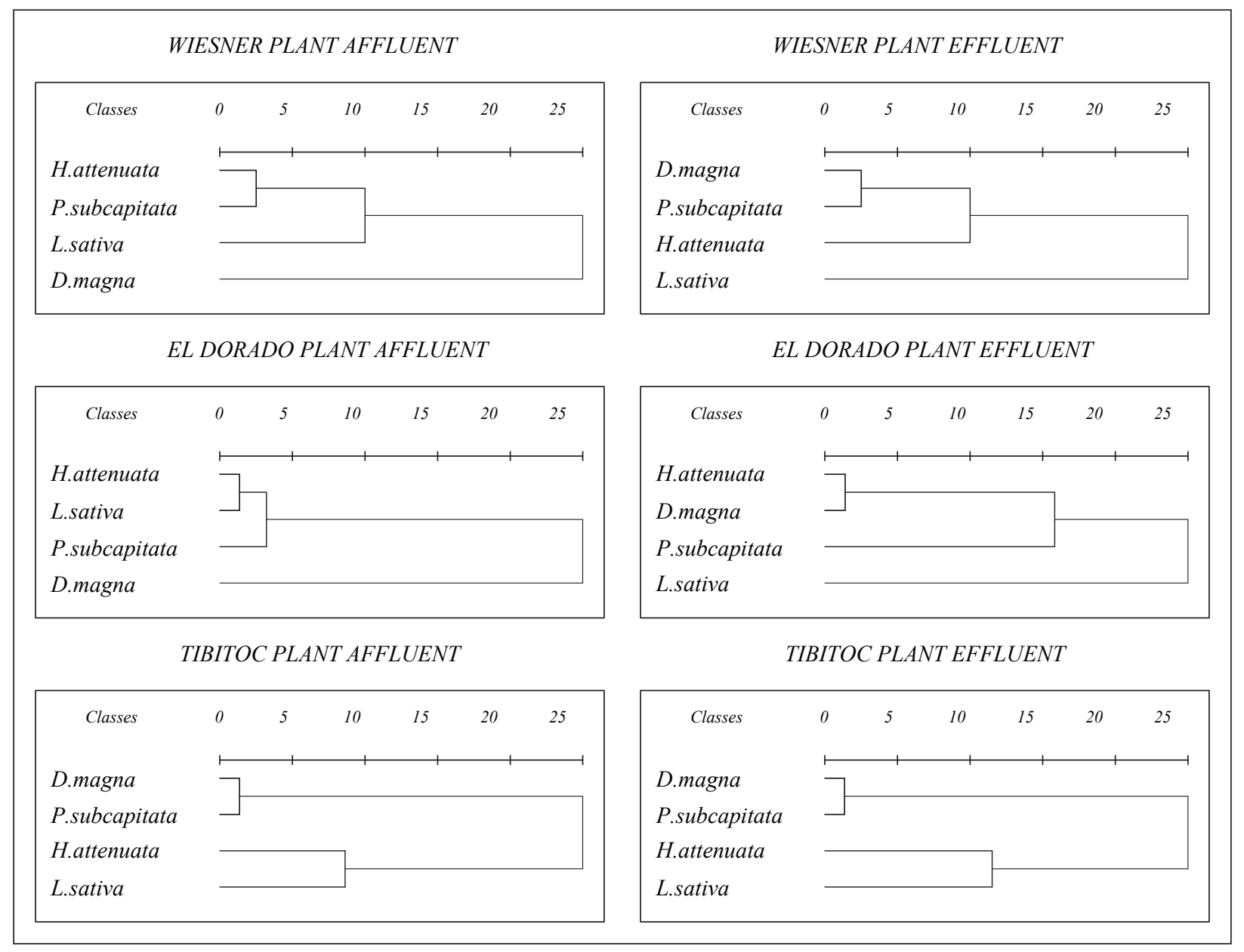

Figure 1. Dendrograms for the affluent and effluent of the water treatment plants Francisco Wiesner, El Dorado and Tibitoc with $H$. attenuata, D magna, $P$. subcapitata and L. sativa.

below $5 \%$ in El Dorado. Based on these results the battery to the affluents of the treatment plants includes the following organisms: Francisco Wiesner: H. attenuata, P. subcapitata and P. leioghnathi; El Dorado: H. attenuata, L. sativa and P. leioghnathi; and Tibitoc: D. magna, P. subcapitata and $P$. leioghnathi. In the case of the effluents, Francisco Wiesner: D. magna, P. subcapitata and P. leioghnathi; El Dorado: H. attenuata, P. subcapitata and P. leioghnathi; and Tibitoc: D. magna, P. subcapitata and P. leioghnathi. This selection included representatives of the food chain for animals, plants and bacteria.

\section{Discussion}

The results of bioassays with $H$. attenuata demonstrate an increased sensitivity of this organism for affluent or raw water from the three water treatment plants, a finding that coincides with the results obtained by Castillo et al. (30) who assessed wastewater with $H$. attenuata and D. magna and found that $H$. attenuata shows a greater sensitivity to this type of water. On the other hand, Pardos (24) reported that in $35.7 \%$ of the wastewater studied, mortality was observed for $H$. attenuata and $71.4 \%$ sublethal responses. In subsequent studies, Pardos et al. (31) compared the sensitivity of $H$. attenuata and Microtox (Vibrio fischeri) in wastewater samples and higher sensitivity was observed by $H$. attenuata, attributing the observed toxicity for this organism to ammonia levels.

Slabbert and Venter (32) evaluated domestic sewage effluent and industrial wastewater with D. magna and $S$. capricornutum and toxic activity was detected between 20 and $100 \%$ for both indicators. In our study we observed in D. magna as in P. subcapitata toxicity levels above $20 \%$ 
in a single sampling event in affluents of Wiesner and $\mathrm{El}$ Dorado, while in Tibitoc toxicity levels were lower. By contrast, Kontana et al. (33) found mortality rates of 50\% of D. magna in most wastewater samples. The toxicity values found in the affluents of this study showed that $P$. subcapitata presents both inhibition and overgrowth in all the events analysed in the three treatment plants. By contrast D. magna has little sensitivity to this type of water. Similar results reported $\mathrm{Ra}$ et al. (34) in assessing wastewater with S. capricornutum and D. magna, who found that $33 \%$ of the samples showed acute toxicity to D. magna compared to $92 \%$ with S. capricornutum.

In assessing the effect of wastewater toxicity on $H$. attenuata, Bacillus cereus, Panagrellus redivivus, D. magna, L. sativa, and Oncorhynchus mykiss, Castillo et al. (30) found that $H$. attenuata showed the highest sensitivity in this type of water, while $L$. sativa had lower sensitivity even compared to $P$. subcapitata. Pica-Granados et al. (35) and Arkhipchuk et al. (36) reported inhibitory effects against organic substances, but Bohórquez and Campos (37) showed growth-stimulating effects of this alga.

In the case of effluent or potable water, D. magna showed higher sensitivity compared to other organisms evaluated. Cao et al. (18) reported similar results with D. magna when assessed town's secondary effluents before and after disinfection with chlorine, noting that this organism was more sensitive in samples treated with chlorine. Garzón (38) evaluated the toxicity of drinkable water from the Bogotá River and found the highest sensitivity with $H$. attenuata, showing $\mathrm{EC}_{50}$ of 21.1 and $\mathrm{LC}_{50}$ of 30.2. L. sativa and $S$. capricornutum showed moderate sensitivity, whereas in D. magna mortality was not observed, probably because chlorine was inactivated after purification.

In the vegetable models, although there was a similar inhibition effect between Pseudokirchneriella and Lactuca, microalgae showed signs of toxicity reflected in the cell overgrowth. On the other hand, the bacterial model $P$. leioghnathi showed sensitivity only against inorganic compounds in a sample of the effluent of El Dorado plant.

The results obtained in the CA do not coincide entirely with those obtained in bioassays of toxicity in relation to the animal model in the affluent of The Tibitoc plant, since the results suggest the use of $D$. magna, but in the affluent of the three water treatment plants $H$. attenuata appears to be more sensitive. In the effluent of El Dorado plant the cluster analysis suggests the use of $H$. attenuata, but in the results of the three water treatment plants $D$. magna shows greater sensitivity. This could be explained by the number of samples and / or the fact of using only the results in the concentration of $100 \%$. In many cases, positive results are obtained at lower concentrations, but these data are lost when entering into the analysis only the concentration of $100 \%$. In these cases it is suggested to analyse a larger sample before making a decision and to take into account the initial results of the toxicity organisms tested. Such information is appropriate for decision making.

For the selection of organisms that are part of the battery of bioassays other tools can be used as suggested by Pandard et al. (15) who used CA as well as Principal Component Analysis (PCA) to select a battery of bioassays as part of the classification of hazardous waste of the Directive 91/689-CEE (39). In this case, they included $L$. sativa and $P$. subcapitata as vegetable models, E. foetida, D. magna and $C$. dubia as animal models and $V$. fischeri as a model for assessing bacterial toxicity in 40 residues. The authors note that the multivariate analysis can reduce the number of tests without changing the characteristics of the waste and that the combination of CA with PCA provides more robustness to the hierarchy of groups. Similarly, RojičkováPadrtová(14) used only PCA to select a battery of bioassays including 6 microarrays and three standard acute toxicity tests in environmental samples. The analysis showed three main components that explain $60 \%$ of the variance of the variables as follows: the first component ( $P$. subcapitata, T. platyurus, D. magna and B. calyciflorus) explains $26 \%$, the second component (C. dubia, S. ambiguum) explains $20.6 \%$ and the third component (V. fischeri) explains $13.5 \%$. Results indicate that such selection is possible with this tool, allowing to conclude that the battery may contain $P$. subcapitata, B. calyciflorus, T. platyurus and V. fischeri.

Devillers (13) and Pandard (15) suggest a combination of multivariate analysis such as nonlinear mapping and principal component analysis among others, to provide more information about the analysed matrix for optimal selection. However, the structure and amount of data obtained in the three treatment plants did not meet the requirements of these tools, the reason why they were not implemented.

\section{Conclusions}

Based on the results obtained, we suggest the use of $H$. attenuata, $P$. subcapitata and $P$. leioghnathi to evaluate the affluents of the three water treatment plants and $D$. magna, P. subcapitata and P. leioghnathi for effluents. This decision takes into account the variability in the response of organisms, the type of water analysed, the taxonomic group within the food chain and the cost-benefit. Similarly, it would be more convenient for the laboratories responsible of the management of treatment plants to use the same battery 
in all the three cases. Multivariate analysis and cluster analysis proved to be useful tools for selecting a battery of bioassays. The results for the effluents are useful as early warning systems for drinking-water treatment plants, but they do not determine by themselves the toxicity effects on the consumer. To rule out effects on human health other tests for an extended period of time are needed.

\section{Financial support}

The Empresa de Acueducto y Alcantarillado de Bogotá$E A A B$ (Bogotá Water and Sewerage Company) provided technical and financial support for the implementation of this project.

\section{Conflict of interest}

The authors have no conflict of interest.

\section{References}

1. Tothill IE, Turner APF. Developments in bioassay methods for toxicity testing in water treatment. Trends in Analytical Chemistry 1996; 15 (59): 178-187.

2. Párvez S, Venkataraman C, Mukherj S. A review on advantages of implementing luminescence inhibition test (Vibrio Fischeri) for acute toxicity prediction of chemicals. Environment International 2006; 32: 265 - 268.

3. Wang LS, Wei DB, Wei J, Hua HY. Screening and estimating of toxicity formation with Photobacterium bioassay during chlorine disinfection of wastewater. Journal of Hazardous Materials 2007; 141: 289-294.

4. Movahedian H, Bina B, Asghari GH. Toxicity evaluation of wastewater treatment plant effluents using Daphnia magna. Journal Environmental Health Science Engineering 2005; 2 (2): 1-4.

5. Bayo J, Angosto JM, Gómez-López MD. Ecotoxicological screening of reclaimed disinfected wastewater by Vibrio fischeri bioassay after a chlorination-dechlorination process. Journal of Hazardous Materials 2009; 172: $166-171$

6. Silva PM, Fabrin-Neto JB, Gomes de Moraes S, Assalin MR, Dura'n N, Haun M. Comparative toxicity of effluents processed by different treatments in V79 fibroblasts and the Algae Selenastrum capricornutum. Chemosphere 2006; 62: 1207-1213.

7. Johnson I, Hutchings M, Benstead R, Thain J, Whitehouse P. Bioassay selection, experimental design and quality control/assurance for use in effluent assessment and control. Ecotoxicology 2004; 13: 437-447.

8. Oberholster PJ, Botha AM; Cloete TE. Biological and chemical evaluation of sewage water pollution in the Rietvlei nature reserve wetland area. Journal of Hazardous Materials 2008; 156: 184-192.

9. Keddy C, Greene J, Bonnell M. Review of whole organisms bioassay: soil, freshwater sediment and freshwater assessment in Canada. Ecotoxicology and Environmental Safety 1995, 30: 221-251.

10. Beauregard T, Ridal J. Evaluation of six simple bioassays for the determination of drinking water quality-Canadian results. Environmental Toxicology 2000; 15 (4): 304-311.

11. Mandal R, Hassan N, Murimboh J, Chakrabarti C, Back M. Chemical speciation and toxicity of nickel species in natural waters from the Sudbury area (Canada). Environmental Science and Technology 2002; 36: 1477-1484.

12. Mitchell J, Burgess J, Stuetz R. Reviews developments in ecotoxicity testing. Environmental Science \& Biotechnology 2002; 1: 169-198.

13. Devillers J, Elmouaffek A, Zakarya D, Chastrette M. Comparison of ecotoxicological data by means of an approach combining cluster and correspondence factor analyses. Chemosphere 1998; 17: 633-646.

14. Rojíčková-Padrtová R, Maršálek B, Holoubek I. Evaluation of alternative and standard toxicity assays for screening of environmental samples: selection of an optimal test battery. Chemosphere 1998; 37: 495-507.

15. Pandard P, Devillers J, Charissou A, Poulsen V, Jourdain M, Férar J, Grand C, Bispo A. Selecting a battery of bioassays for ecotoxicological characterization of wastes. Science of the Total Environment 2006; 363: 114-125.

16. Rizzo L, Belgiorno V, Gallo M, Meric S. Removal of THM precursors from a High- alkaline surface water by enhanced coagulation and behavior of THMFP toxicity on D. magna. Desalination 2005; 176: 177-188.

17. Ra JS, Cheun BL, Chang NIK, Kim SD. Comparative whole effluent toxicity assessment of wastewater treatment plant effluents using Daphnia magna. Bulletin of Environmental Contamination and Toxicology 2008; 80: 196-200.

18. Cao N, Yang M, Zhang Y, Hub J, Ikec M, Hirotsujid J, Matsuic $\mathrm{H}$, Inouec D, Seic K. Evaluation of wastewater reclamation technologies based on in vitro and in vivo bioassays. Science of the Total Environment 2009; 407: 1588-1597.

19. Quinn B, Gagné F, Blaise C. The effects of pharmaceuticals on the regeneration of the cnidarian, Hydra attenuata. Science of the Total Environment 2008; 402: 62- 69. 
20. Forget G, Gagnon P, Sanchez A, Dutka B. Overview of methods and results of the eight countries International Development Research Centre (IDRC) WaterTox Project. Environmental Toxicology 2000; 15 (4): 264-276.

21. Castillo LE, Martínez E, Ruepert C, Savage C, Gilek M, Pinnock M, Solis E. Water quality and macroinvertebrate community response following pesticide applications in a banana plantation, Limon, Costa Rica. Science of the Total Environment 2006; 367: 418-432.

22. Andrade LF, Davide LC, Gedraite LS. The effect of cyanide compounds, fluorides, aluminum, and inorganic oxides present in spent pot liner on germination and root tip cells of Lactuca sativa. Ecotoxicology and Environmental Safety 2010; 73: 626-631.

23. Cho CW, Phuong TTP, Jeon YC, Vijayaraghavan K, Choe WS, Yun YS. Toxicity of imidazolium salt with anion bromide to a phytoplankton Selenastrum capricornutum: Effect of alkyl-chain length. Chemosphere 2007; 69: 1003-1007.

24. Pardos M, Benninghoff C. Acute toxicity of polish (waste) water with a microplate based Hydra attenuate assay: A comparation with the Microtox test. Science of the Total Environment 1999; 243/244: 141-148.

25. Dutka, B. Methods for microbiological and toxicological analysis of water, wastewaters and sediments: National Water Research Institute (NWRI), Environment Canada; Burlington, Ontario, Canadá. 1989, 140p.

26. Trottier S, Blasie C, Kusui T, Jhonson EM. Acute toxicity assessment of aqueous samples using a microplatebased Hydra attenuata assay: technical methodology. Environment Toxicology Water Quality 1997; 12: 265-271.

27. Dutka, B. Short-Term root elongation toxicity bioassay. Methods for toxicological analysis of waters, wastewaters and sediments: National Water Research Institute (NWRI), Environment Canada., Canada. 1989, 320p.

28. Short-term methods for estimating the chronic toxicity of effluents and receiving waters to freshwater organisms., $3^{\text {th }}$ ed. US EPA, EPA/600/4-91/002. Philip Lewis AL, Klem DJ, Lazorchak JM. 1994.

29. Standard Methods for the examination of water and wastewater, $21^{\text {th }}$ ed., American Public Health Association, Ap. 8010G., Washington, D.C., APHA, 2005, 8-20, 8-23p.
30. Castillo GC, Vila IC, Neild E. Ecotoxiciy assessment of metals and wastewater using multitrophic assays. Environmental Toxicology 2000; 15: 370-375.

31. Pardos M, Benninghoff C, Guéguen C, Thomas R, Dobrowolski J, Dominik J. Water ecotoxicity studies in Cracow (Poland) using Hydra attenuata, Selenastrum capricornutum y Microtox toxicity test. Lakes \& Reservoirs. Research and Management 2000; 5: 75-81.

32. Slabbert JL, Venter EA. Biological assay for aquatic toxicity testing. Water Science and Technology 1999; 39 (10-11): 367-373.

33. Kontana C, Papadimitriou A, Samaras P, Zdragas A, Yiangou M. Bioassays and biomarkers for ecotoxicological assessment of reclaimed municipal wastewater. Water Science and Technology 2008; 57 (6): 947-953.

34. Ra JS, Kim HK, Chang NI, Kim SD. Whole Effluent Toxicity (WET) Test on wastewater treatment plants with Daphnia magna and Selenastrum capricornutum. Environment Monitoring Assessment 2007; 129: 107-113.

35. Pica-Granados Y, Trujillo GD, Hernández HS. Bioassay Standardization for Water Quality Monitoring in Mexico. Environmental Toxicology 2000; 15 (4): 322-330.

36. Arkhipchuk VV, Romanenko VD, Malinovskaya MV, Kipnis LS, Solomatina VD, Krot YG. Toxicity Assessment of Water Samples with a set of Animal and Plant Bioassays: Experience of the Ukrainian Participation in the WaterTox program. Environmental Toxicology 2000; 15 (4): 277-286.

37. Bohórquez PY, Campos MC. Evaluación de Lactuca sativa y Selenastrum capricornutum como indicadores de toxicidad en aguas. Universitas Scientiarum 2007; 12 (2): 83-98.

38. Garzón C. Evaluación de la calidad toxicológica y microbiológica de la fuente de abastecimiento del municipio de Agua de Dios en Cundinamarca. Tesis de Maestría. Universidad Nacional de Colombia, Bogotá, 2002, 310p.

39. EC, 1991. Council Directive 91/689/ECC. Of 12 December 1991 on hazardous waste. Official Publications of the European Communities 1991; 377; 0020-7 [28/03/2011]. 